estimates are $h^{2}=0.36\left(s_{\mathrm{h}}{ }^{2}=0.172\right)$ for three year old trotters and $h^{2}=0.25\left(s_{\mathrm{h}}^{2}=0.048\right)$ over all age groups. The expected selection response after selection on racing performance of three year old stallions and mares has been calculated. It amounts to 2.03 seconds per generation if selection is only applied on the male path, and 2.57 seconds per generation after selection on the male and the female path. Assuming a generation interval of five years on the male side and of ro years on the female side, the expected selection response per year amounts to 0.34 seconds or $0 .+\mathrm{p}$. Ioo. The record times of trotters have increased during a period of 120 years by I minute which makes an average increase of 0.50 seconds per year.

\title{
GENETISCHE KOVARIANZ ZWISCHEN UMNITTELBAREM UND MÜTTERLICHEM EFFEKT JE NACH DER RICHTUNG DER INNERFAMILIENMÄSSIGEN SELEKTION FÜR DAS KÖRPERGEWICHT IM ALTER VON 2I TAGEN BEI MÄUSEN
}

\section{T. Slawinski. - Agricultural Academy Institute of Biological Basis of Animal Breeding, Wars- zawa, Poland.}

Im Ergebnisse der während der Io Generationen geführten Zweirichtungsselektion für das Körpergewicht im Alter von 2 I Tagen wurden 3 Linien von Mäusen, und zwar : C - mit grossem Körpergewicht, L - mit kleinem Körpergewicht und $\mathrm{O}$ - nichtselektionierte Kontrollinie, erhalten. Nach 8 Generationen der Selektion wurde ein Versuch durchgeführt, in welchem die Jungmäuse aller 3 Linien den Weibchen zur Fütterung kreuzmässig untersetzt waren. Im Ergebnisse wurden 6-Stück-Mäusegruppen erhalten, die volle durch eigene Mütter (je 2 Stück) und durch die Weibchen zweier übrigen Linien (auch je 2 Stück) aufgezüchteten Geschwister umfassten. Auf Grund der Messungen von 1108 Mäusen der Ausgangspopulation wurden die Körpergewichtsparameter genetisch abgeschätzt. Auf Grund des Selektionseffektes wurden unmittelbare und korrelierte Reaktionen auf Selektion, berechnet als Regression von Differenzen zwischen den Mittleren der den Generationen entgegengestellten Linien, abgeschätzt. Auf Grund der Differenz zwischen der Kovarianz der vollen durch eigene Mütter und dieser durch die Ammen genetisch unterschiedlicher Linien aufgezüchteten Geschwister wurde die genetische Kovarianz zwischen unmittelbarem und postnatalem mütterlichem Effekt ermittelt.

Es wurde eine negative genetische Kovarianz zwischen obigen Effekten in selektionierten Linien und eine positive genetische Kovarianz in der Kontrollinie erhalten.

Im Zusammenhang mit den genetisch hohen Korrelationskoeffizienten zwischen dem Körpergewicht im Alter von 12,42 und 56 Tagen $\left(r_{\mathrm{G}}=0,8\right.$ bis $\left.\mathrm{I}, \mathrm{o}\right)$ und einem unterschiedlichen Zeichen der genetischen Kovarianz in den selektionierten Linien und in der Kontrollinie wurde die Hypothese gestellt, dass die Korrelation zwischen dem unmittelbaren genetischen Effekt des Körpergewichte und dem genetischen postnatalen Effekt vom nichtpleiotropischen Charakter sei.

\section{RECOMBINATION OF BLOOD GROUP FACTORS IN THE $B$ SYSTEM IN CATTLE}

\section{Z. Dorynek, A. Kaczmarek. - Agricultural Academy, Posnaì, Poland.}

Bei I 949 Kälbern wurden die Blutgruppen in Io Systemen unter Anwendung von 58 Sera bestimmt, wobei 20 Sera zur Identifizierung der zum $B$-System gehörenden Antigene dienten. In zwei Fällen wurde eine irregulare Blutgruppenvererbung im $B$-System festgestellt, was als Folge von Crossing-over betrachtet werden kann.

\section{EXTENDED PART-LACTATIONS ON THE BASIS OF IAST TESTDAY MILK YIELD}

\footnotetext{
T. Aurax. - Department of Animal Genetics and Breeding, Agricultural University of Norway, Ås-NLH, Norway.

A study concerning extention of part-lactation records is done on about 6200 first and 4 I 50 second - to fifth lactations records from the milk recording in Norway. The monthly and cumulative montly milk yield records were pre-adjusted for the effect of age, month of calving, herd, length of first period and calving interval.
} 
Studies of the genetic and phenotypic correlations between different information from the lactation showed that the last test was the single information with the highest correlations with the unknown part of the lactation.

Five different extention equations were compared : three ratio and two regression equations. The ratio equations were : I) a ratio extention of part-lactation to total lactation directly and 2) two ratio equations to estimate the rest-lactation from the last test. The regression equations were a linear regression of the rest-lacation on the last test and a multiple regression of partlactation, last-test and test before last test on total total lactation.

The last method was found to be the best in terms of the precision of the extention, but the three methods using last test to estimate rest-lactation were very close to the multiple regression.

It is concluded, with reference to the applicability, that the ratio equations to estimate the rest-lactation from the last test should be prefered in practice.

\section{RELATIONSHIPS BETWEEN THE RESISTANCE TO MASTITITS AND SOME UDDER AND MILKING CHARACTERISTICS}

\section{J. Philipsson, A. M. Luxdeekg. --. Department of Animal Breeding, Agricultural College, S-i.50 Or UPPSA L.A 7. Sweden.}

The relationships between the resistance to mastitis, measured by the CMT, on the one hand and ease of milking and various characteristics of udder and teats, on the other, were studied on 8 farms with Swedish Red and White (SRB) cows and 9 farms with Swedish Friesian $(S L B)$ cows.

The correlations between rate of mastitis and ease of milking were very low and generally non-significant. The relationships with the proportion of the milk from the fore udder were significant in most cases. Large proportions are correlated to higher rates of mastitis in the hind quarters and small proportions to higher rates of mastitis in the fore quarters. Significant correlations were also found with udder height, while other relationships were weaker.

\section{EVIDENCE FOR A POSSIBLE INFLUENCE OF THE FETUS IN THE MILK YIELD OF THE DAM}

\section{H. SkJervold, E. Fimland. - Institute of Animal Genetic and Breeding, Agricultural University of Norway, $\AA_{s-N L H, \text { Nonway. }}$}

It has been observed from the literature that hormone activity of the fetal placenta stimulate mammary developements during the pregnancy. The milk production is also indicated to be limited by the number of milk-synthesizing cells. Observing these two findings together may suggest a working hypothesis that the genotype of the fetus affects the milk production of the clam.

In order to test this hypothesis, first lactation cows calved in the fall were used. Altogether four production years were analysed. The data contained $t^{8} 852$ lactations and 1247 sires of the calves. The characters considered were lactation yield and maximum daily yield. The lactation yield was corrected for age and expressed as deviation from the herd-average .The maximum daily yield was corrected for the herd-average by using linear regression.

The components of variance were obtained by nested half-sib analysis. The components of variance of the sire of the calves were estimated by nesting the sires of the cows within the sires of the calves.

The fetal sire effect on the milk production of the dam was expressed as the coefficient of correlation between the phenotype of milk production of the dam and the genotype of the sire of the calf. The estimates of these correlations range from 0.08 to 0.13 for lactation yield and from 0.07 to 0.09 for maximum daily yield. These coefficients were all significantly different from zero.

The genetic correlation estimated between the proof of the sire of the dam and the proof of the same bull as calf sire was essentially zero and non-significant. 